\title{
Observations on the life history and habits of a tropical sawfly, Sericoceros mexicanus (Kirby), (Hymenoptera: Argidae) on Roatán Island, Honduras
}

\author{
by William M. Ciesla ${ }^{1}$
}

\begin{abstract}
Observations on the life history and habits of a tropical sawfly, Sericoceros mexicanus, on Roatán Island, Honduras, during January 2002, are reported. This sawfly occurs in southern Mexico and Central America where it feeds on the foliage of Coccoloba spp. On Roatán Island, the only host is seagrape, C. uvifera, a small to medium tree, which occurs on sandy beaches just above tide line. The adults are colourful insects and relatively strong fliers. They swarm around host trees on warm, sunny days and during cool or overcast periods, rest on seagrape foliage and branches. In 2002, a period of peak adult activity occurred between January 8 and 10. Eggs are deposited in circular or slightly oval clusters on the undersides of seagrape leaves. Mean egg cluster size is 32.7, range 7-85. Female adults remain with the egg cluster until they die. Eggs hatch within two or three days of oviposition and the larvae feed gregariously on the edges of seagrape leaves, consuming all of the leaf tissue except the major veins. Larvae undergo six instars. However, the small number of instar VI larvae collected suggests that female larvae may undergo an extra instar, as is the case with other species of sawflies. Pupation occurs in parchment-like cocoons attached to leaves, leaf petioles and branches of seagrape. Occasionally, cocoons are attached to wooden surfaces such as picnic benches. A few instar VI larvae were seen with symptoms suggesting virus infection. While heavily infested trees can suffer complete defoliation, the insect appears to cause little or no permanent damage. Local residents regard the insect as a curiosity rather than a pest and report at least two periods of defoliation a year-January and August.
\end{abstract}

Key words: Sericoceros mexicanus, seagrape, Coccoloba uvifera, sawflies, defoliation, tropical forest insects, forest insects

Les observations sur le mode de vie et les habitudes d'une mouche à scie tropicale, Sericoceros mexicanus, sur l'île de Roatán au Honduras en janvier 2002, sont décrites dans ce texte. Cette mouche à scie se retrouve dans le sud du Mexique et en Amérique centrale et se nourrit du feuillage du genre Coccoloba. Sur l'île de Roatán, le seul hôte est le C. uvifera, un arbre de petite à moyenne taille que l'on retrouve sur les plages sablonneuses juste au-dessus de la zone intertidale. Les adultes sont des insectes colorés qui déplacent relativement bien en vol. Ils volent autour des arbres-hôtes au cours des journées chaudes et ensoleillées et se posent sur le feuillage et les branches du C. uvifera au cours des périodes fraîches ou ennuagées. En 2002, une période de pointe de l'activité des adultes s'est produite entre les 8 et 10 janvier. Les œufs sont déposés en grappes circulaires ou largement ovales à l'endos des feuilles de l'hôte. La quantité moyenne d'œufs dans les masses est de 32,7, variant de 7 à 85 . La femelle adulte demeure avec la masse d'œufs jusqu'au moment de sa mort. Les œufs éclosent entre deux et trois jours après la ponte et les larves se nourrissent en groupe sur les bords des feuilles de $C$. uvifera, s'alimentant de tous les tissus foliaires à l'exception des nervures principales. Les larves vivent six stades de développement. Cependant, le faible nombre de larve de stade VI récoltées laisse sous-entendre que les larves femelles pourraient entreprendre un stade supplémentaire, comme c'est le cas parmi les autres espèces de mouche à scie. La transformation en chrysalide de produit dans des cocons ressemblant à du parchemin attachés aux feuilles, aux pétioles des feuilles et aux branches du $C$. uvifera. Parfois, les cocons sont attachés aux surfaces de bois comme les bancs de pique-nique. Quelques larves du stade VI démontraient des symptômes laissant croire à une infection virale. Même si les arbres infestés peuvent subir une défoliation complète, l'insecte semble causer peu ou pas de dommage permanent. Les résidents locaux considèrent l'insecte comme une curiosité plutôt qu'un ravageur et rapportent au moins deux périodes de défoliation par an, soit en janvier et en août.

Mots-clés : Sericoceros mexicanus, Coccoloba uvifera, mouches à scie, défoliation, insectes des forêts tropicales, insectes forestiers

\section{Introduction}

While visiting Roatán Island, a 50-km long by $2-4$ km-wide island in the Caribbean Sea, about $50 \mathrm{~km}$ off the coast of Honduras (Fig. 1), I detected defoliation on seagrape, Coccoloba uvifera, a common tree of coastal areas. Closer inspection of the trees revealed large numbers of adults, eggs, and larvae of a sawfly. The sawfly was subsequently identified as Sericoceros mexicanus (Kirby) (Hymenoptera: Argidae).

The occurrence of large numbers of this insect provided an opportunity to collect data on the life history and habits of a little-known group of sawflies. Reported in this paper are observations made during January 2002 in the West Bay area of Roatán Island. These observations covered nearly a full generation of activity.

\footnotetext{
${ }^{1}$ Forest Health Management International, 2248 Shawnee Court, Fort Collins,
} CO 80525, USA. E-mail: wciesla@aol.com

\section{Background Information Sericoceros}

Smith (1992) recognized 20 tropical American species of Sericoceros. Another species, S. vitellanae, was discovered in Paraguay in 1999 (Smith and Benitez Diaz 2001). They occur from the Mexico south to Argentina with one species present in the West Indies. Most feed on various species of Coccoloba; however, one species is reported from Lonchocarpus spp. and another from Triplaris caracasana (Smith 1992, Smith and Benitez Dias 2001).

Relatively little is known about the life history and habits of the members of the genus Sericoceros. Martorell (1941) 


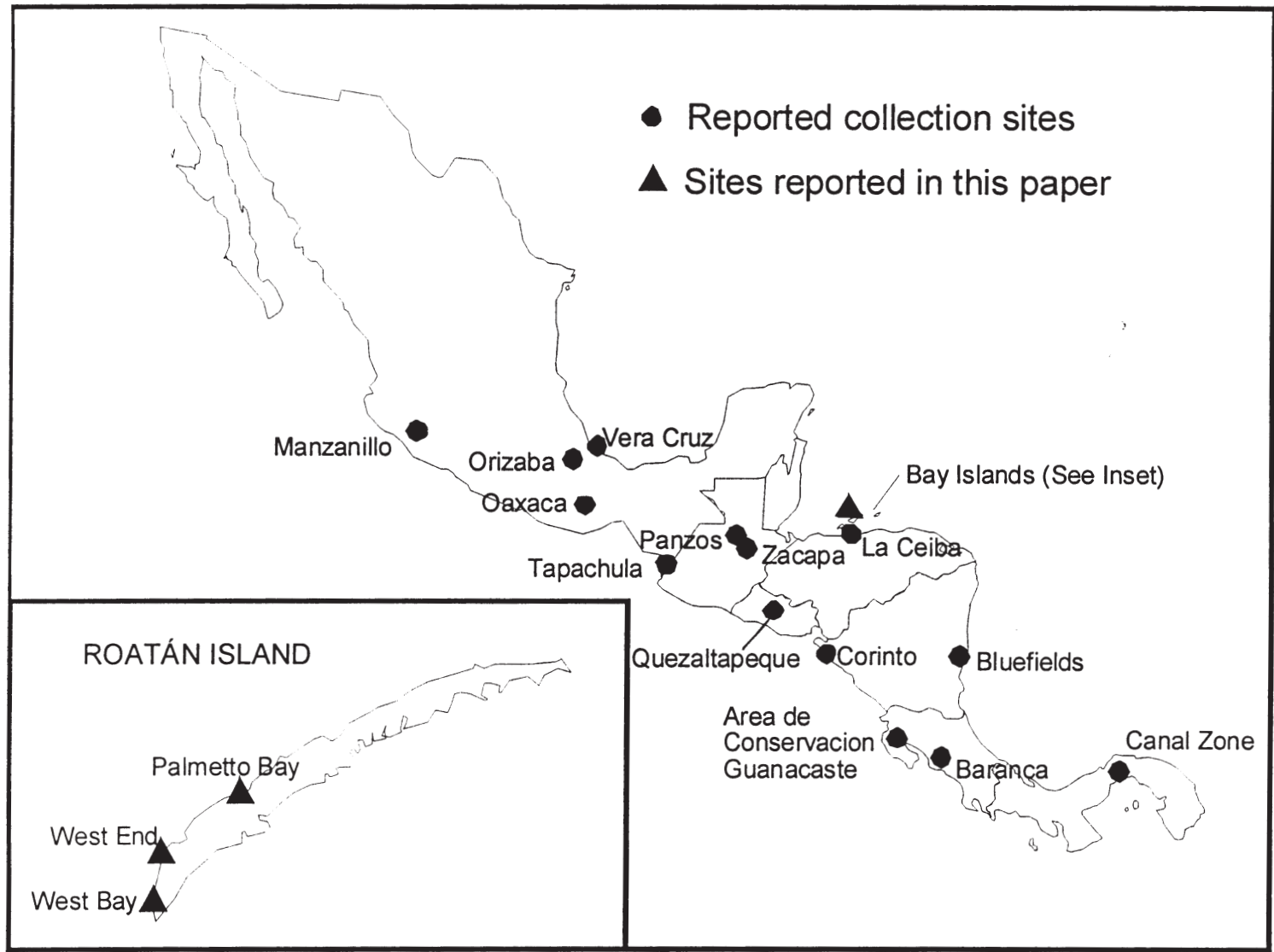

Fig. 1. Collection records for the sawfly, Sericoceros mexicanus.

reported on the life history and hosts of $S$. krugii (Cresson) in Puerto Rico. Sericoceros krugii feeds on several species of Coccoloba indigenous to Puerto Rico and infestations can be found from sea level to the mountains (about 825 meters in elevation). More recently, $S$. krugii has been recorded from the Dominican Republic and St. Thomas, U.S. Virgin Islands (Smith 1992).

Sericoceros mexicanus is known from southern Mexico and Central America and reported hosts include Coccoloba sp., C. uvifera L. (Smith 1992), and C. venosa L. (Family Polygonaceae) (Smith and Janzen 2002) (Fig 1). The collections reported from Roatán Island are a new record for this species; however, they are not far from the mainland Honduras collection site near La Ceiba reported in Smith (1992). Some observations on the biology of $S$. mexicanus, S. gibbus (Klug) and $S$. vumirus Smith are reported from a dry forest ecosystem in the Area de Conservacion Guanacaste in Guanacaste Province, northwestern Costa Rica where $S$. mexicanus was reported feeding on C. venosa (Smith and Janzen 2002).

Sericoceros mexicanus is well known to the local residents of Roatán Island. However, few people apparently realize that the adults and the larvae are different life stages of the same insect. Weavers, originally from Guatemala but now residing in the village of West Bay on Roatán, have incorporated a remarkably accurate and attractive likeness of the female adult into their weavings (Fig. 2). Other residents are aware of periodic defoliation of $C$. uvifera and regard it as nature's way of "pruning" seagrape.

\section{Seagrape}

Seagrape, Coccoloba uvifera, is a small to medium tree, capable of reaching a height of about 7.5 to $9 \mathrm{~m}$ in height. It can take on a variety of shapes, depending upon its location but typically forms a multi-stemmed vase-like shape if left unpruned or is not exposed to high winds or salt spray. The large, almost circular broad, leathery leaves have distinct red veins. The tree produces inconspicuous ivory- coloured flowers on racemes, which develop into grape-like fruits that ripen to a deep purple colour. The grapes are used to make jams and jellies (Gilman and Watson 1993), and, on Roatán, local residents make a wine from the fruit.

The tree is native to seashore regions throughout tropical America. In south Florida, seagrape is used as an ornamental tree and has been successfully grown in urban areas where air pollution, poor drainage, compacted soil and/or drought are common stress factors (Gilman and Watson 1993).

\section{Methods}

Information presented in this paper is based primarily on daily observations made on infested seagrape trees in the West Bay area of Roatán Island, Honduras. All observations were made between 6 and 26 January 2002. Adult sex ratio was determined by examination of randomly selected leaves on seagrape trees during the early morning hours (prior to 07:30) of peak adult activity and recording the sex of every adult sawfly encountered. Periodic collections of larvae were made for instar determination throughout the observation period. Larval head 


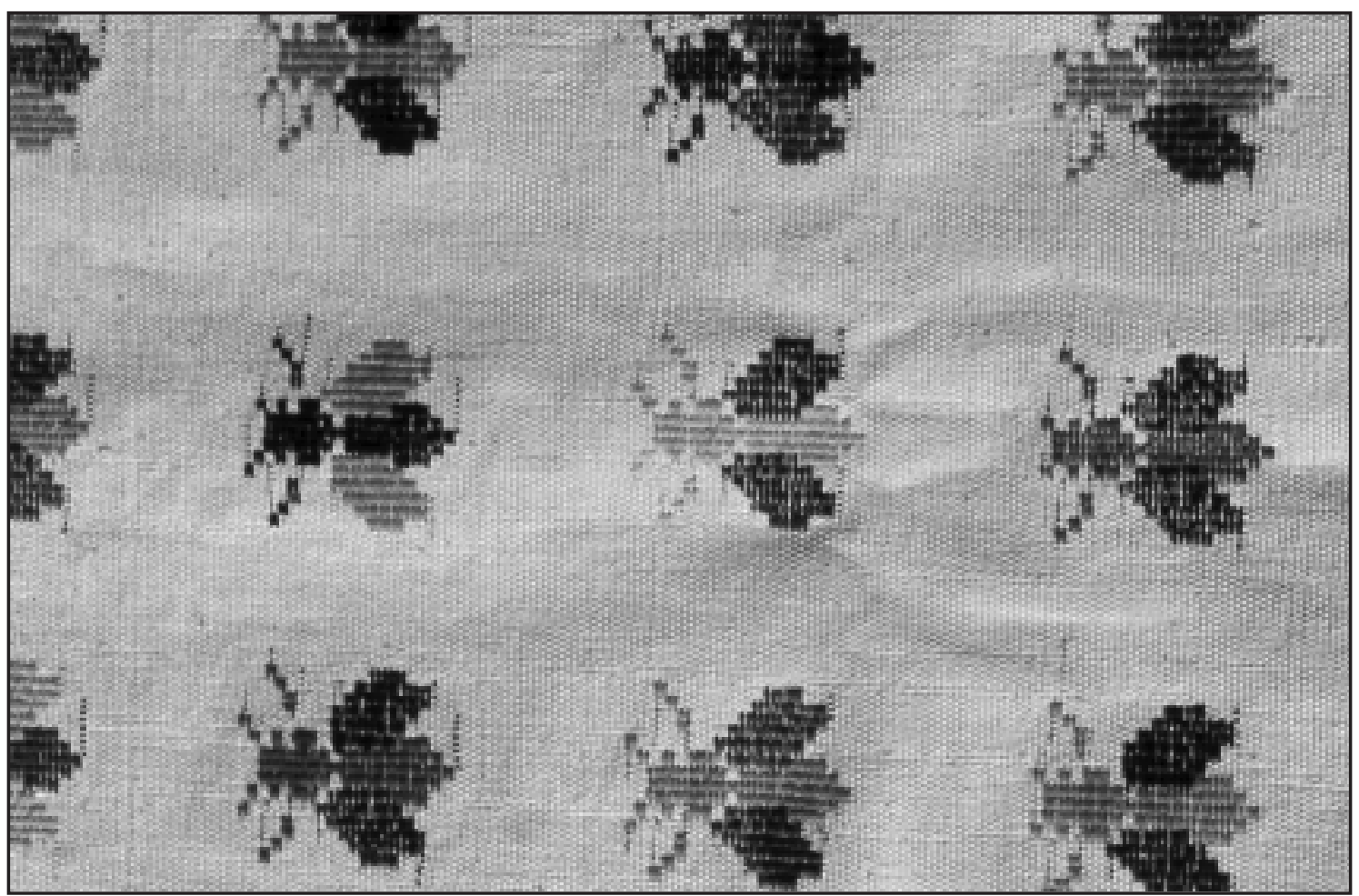

Fig. 2. Weaving by local artisans in West End, Roatán Island, Honduras, depicting female Sericoceros mexicanus.

capsule widths were measured across the widest part of the head when viewed dorsally using a binocular microscope.

\section{Description of Stages \\ Adults}

The adults are attractive, colourful sawflies. Females are approximately $12 \mathrm{~mm}$ in length with a bright red-orange thorax and abdomen; wings clear with conspicuous black veins; head, antennae, and legs dark brown to black; and antennae filiform. Males are slightly smaller, $8-10 \mathrm{~mm}$ long; the thorax and ventral surface of the abdomen bright red-orange and the dorsal surface of each abdominal segment red-orange with a black band; wings are similar to the female but smaller; head, antennae, and legs dark brown to black; and antennae forked at the third antennal segment giving the appearance of four antennae, with the third antennal segment furcate.

\section{Eggs}

Eggs of S. mexicanus are virtually identical to the description of eggs of S. krugii provided by Martorell (1941). They are laid separately in circular to slightly oval clusters on the undersides of seagrape leaves. Eggs are bright red in colour and about $2 \mathrm{~mm}$. long when first laid, turning into various hues of pale orange or pink while increasing in size. According to Martorell (1941), increase in egg size is a general characteristic of sawflies and is probably due to absorption of moisture before hatching. Mean egg cluster size, based on counts of 37 egg clusters is 32.7 (range 7-85). After hatching, the egg chorions are collapsed and white in colour.

\section{Larvae}

First instar larvae are orange at eclosion but take on a greenish cast as soon as they begin feeding. For later instars, the head capsule is pale yellow immediately after moulting and changes to medium or dark brown. Black eyespots are conspicuous even on larvae with dark brown head capsules. Thoracic legs are brown and the prolegs are white and non-functional. The body surface is shiny and yellow-green in colour on the dorsal and lateral surfaces, turning to yellow on the ventral surface. Both thoracic and abdominal segments are adorned with rows of small tubercles that become more conspicuous in the latter instars. The last two abdominal segments are often yellow. Overall length of mature (instar VI) larvae is approximately 25-28 mm. A prepupal stage was not seen.

\section{Cocoons}

Cocoons have a parchment-like texture and are beige in colour. Dimensions are approximately $10 \mathrm{~mm}$ long by $4-5 \mathrm{~mm}$ wide. No conspicuous difference in the size of male and female cocoons was observed.

\section{Life History and Habits}

The occurrence of key events in the life history of Sericoceros mexicanus, on Roatán Island, Honduras during January 2002, are summarized in Fig. 3.

\section{Adult Flight, Mating and Oviposition}

One of the most striking aspects of the life history of S. mexicanus observed is the adult flight period. Adults swarm around seagrape trees in large numbers during warm, sunny days, momentarily landing on the upper surface of seagrape leaves and then resuming flight. At peak flight, which occurred from 8-10 January 2002, 25 to 30 adults were commonly seen resting momentarily on a single seagrape leaf. During the cooler periods of the day, or on overcast, rainy days, the adults rest on either the upper or lower leaf surfaces or branch- 


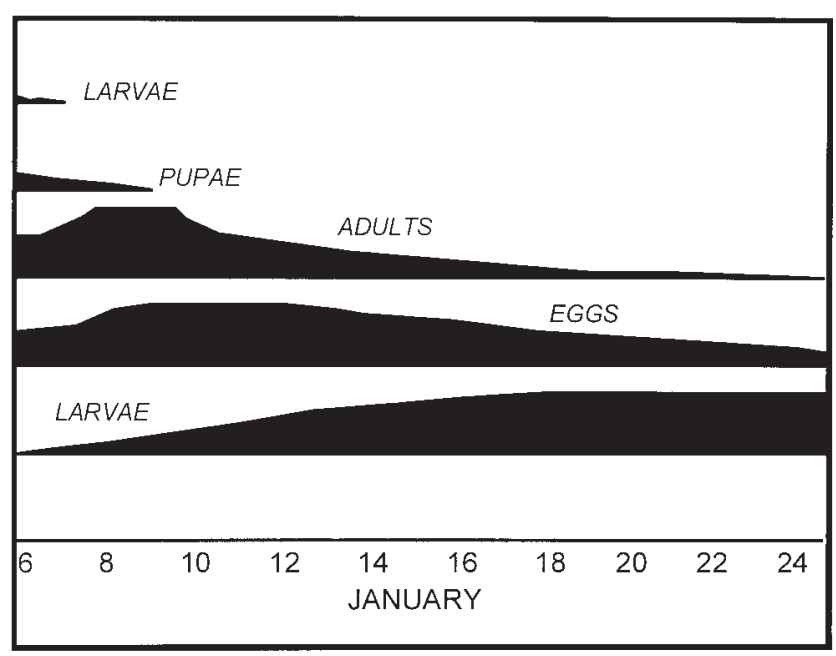

Fig. 3. Life history of Sericoceros mexicanus, Roatán Island, Honduras, January 2002.

es of seagrape. A few adults were seen in flight over open water 2-3 km from shore.

Causal observations throughout the flight period indicated that males were more abundant than females. Sex ratio of adults, based on counts of 192 adults on four seagrape trees on the morning of 9 January, was 2.76 male to 1 female. This is in contrast to Martorell's (1941) report on the life history and habits of $S$. krugii, which indicates that females were more numerous than males. Ideally, sex ratios are determined from rearing studies because they can change during the period of adult activity; however, this was not possible because of the limited time available.
Mating takes place on leaf surfaces and branches of seagrape and oviposition occurs only on the undersides of seagrape leaves. Once an oviposition site is selected, the females stay at that site for the remainder of their lives (Fig. 4). On a few occasions, two females were seen with a single egg mass. Martorell (1941) reports the same habit for $S$. krugii, which he describes as "staying over the egg-mass as if they were brooding the eggs." Smith and Janzen (2002), working in northwestern Costa Rica, describe female, S. mexicanus adults as "standing guard over the eggs." My observations indicate that the females are sluggish during and after oviposition even when probed. They appear to be spent and die at the oviposition site. They do not display the aggressive actions of female Themos olfersii (Klug) (Hymenoptera: Argidae) reported by de Souza Dias (1975), in protecting their eggs.

Female adults were seen on egg clusters during the entire observation period. However, adult activity declined after January 10 and the last flying male adults were seen on January 19. Eggs hatch within two or three days of oviposition. Larvae were frequently seen hatching from egg clusters with the female adult still present.

\section{Larvae}

The larvae feed gregariously on the edges of leaves of seagrape, gradually consuming all of the leaf tissue except the large veins (Fig. 5). They grasp the leaf tissue with their thoracic legs. Their abdominal prolegs are non-functional. When disturbed, the entire larvae colony will extend their abdomens beyond the leaf edge.

If additional unhatched egg clusters occur on the undersides of a leaf being fed on, the larvae feed around the egg cluster, eventually severing it from the leaf. This habit was also reported by Smith and Janzen (2002) for S. mexicanus in northwestern

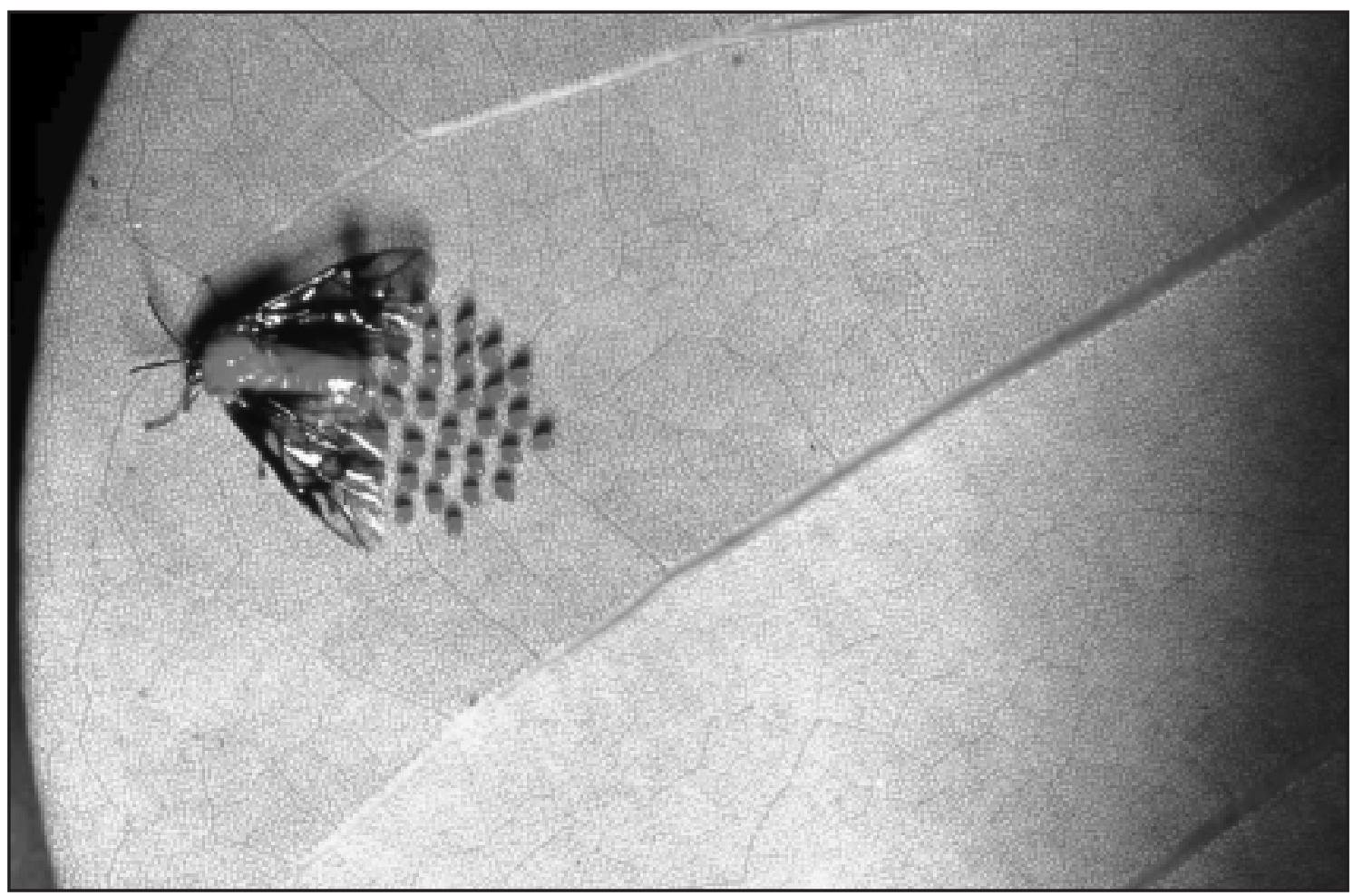

Fig. 4. Female adult of Sericoceros mexicanus with egg cluster. 


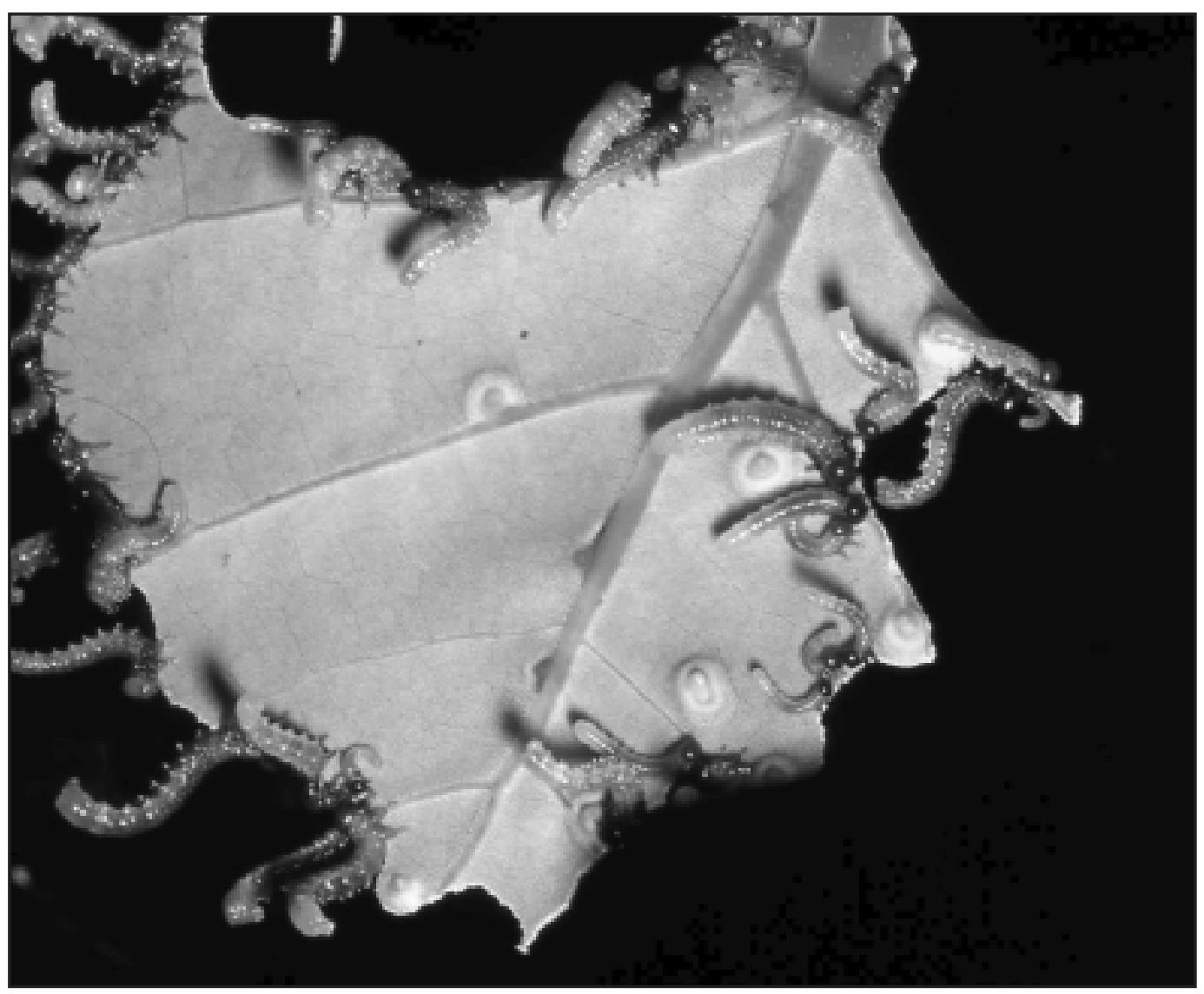

Fig. 5. Colony of Sericoceros mexicanus feeding on the foliage of seagrape.

Costa Rica. A hardened and discoloured patch of tissue on the leaf surface where the eggs are attached, reported by these authors, was not observed on Roatán island.

Measurements of head capsules of 479 larvae indicate six larval instars (Table 1). The sixth instar was not well represented in the series of larvae measured, however $(n=21)$. This may be due to lack of occurrence of instar VI larvae during the observation period or that only a portion of larvae develops into a sixth instar. Studies of conifer-defoliating sawflies of the families Diprionidae and Tenthredinidae indicate that some female larvae undergo one more instar than males. For example, studies by VanDerwerker and Kulman (1974) indicate that male larvae of the yellow-headed spruce sawfly, Pikonema alaskensis (Rohwer), have five instars and that about $66 \%$ of female larvae have an additional sixth instar. Hard et al. (1976) report that male larvae of the hemlock sawfly, Neodiprion tsugae Middleton, in southeastern Alaska have four instars whereas most females have five. Similar data are reported for $N$. nigoscutum Middleton and N. swainei Middleton in Wisconsin (Becker and Benjamin 1964, 1967).

Determination of rate of increase in size of larval instars (mean head capsule width of LI/mean head capsule width of LII, etc.) shows a more or less constant rate of head capsule increase between instars (Table 1) indicating conformance with Dyar's rule of larval growth (Dyar 1890).

A few solitary larvae from the previous generation and two or three LI and LII colonies were seen on January 6, the beginning of the observation period. By January 12-13, larval colonies were common on all seagrape trees in the West Bay
Table 1. Larval head capsule widths of Sericoceros mexicanu

\begin{tabular}{lcccc}
\hline & \multirow{2}{*}{$\begin{array}{c}\text { Number of } \\
\text { Instar }\end{array}$} & \multicolumn{3}{c}{ Head capsule widths (mm) } \\
\cline { 3 - 5 } larvae examined & Range & Mean & Ratio \\
\hline I & 89 & $1.03-1.31$ & 1.16 & - \\
II & 67 & $1.37-1.60$ & 1.49 & 0.78 \\
III & 132 & $1.66-2.06$ & 1.83 & 0.81 \\
IV & 110 & $2.11-2.51$ & 2.31 & 1.26 \\
V & 60 & $2.57-2.97$ & 2.75 & 0.84 \\
VI & 21 & $3.03-3.43$ & 3.16 & 0.87 \\
Total & 479 & & & \\
\hline
\end{tabular}

area. Peak larval activity occurred after January 17 when instars II and III were most abundant. By January 20, instars III and IV were the dominant larval stages and on January 21 , instar V larvae were seen for the first time. Defoliation became noticeable on January 23 but was masked by the appearance of new foliage. By January 24-25, the final days of field observations, most larvae were in instars IV and V although a few unhatched egg clusters and colonies of early instar larvae were still present.

\section{Pupation}

Observations on pupation are based on location of pupal cases from the previous generation of $S$. mexicanus. Larvae construct cocoons of partially chewed leaves in which they pupate. Cocoons are found attached to the branches, leaf petioles and undersides of leaves on seagrape trees, individually or in 


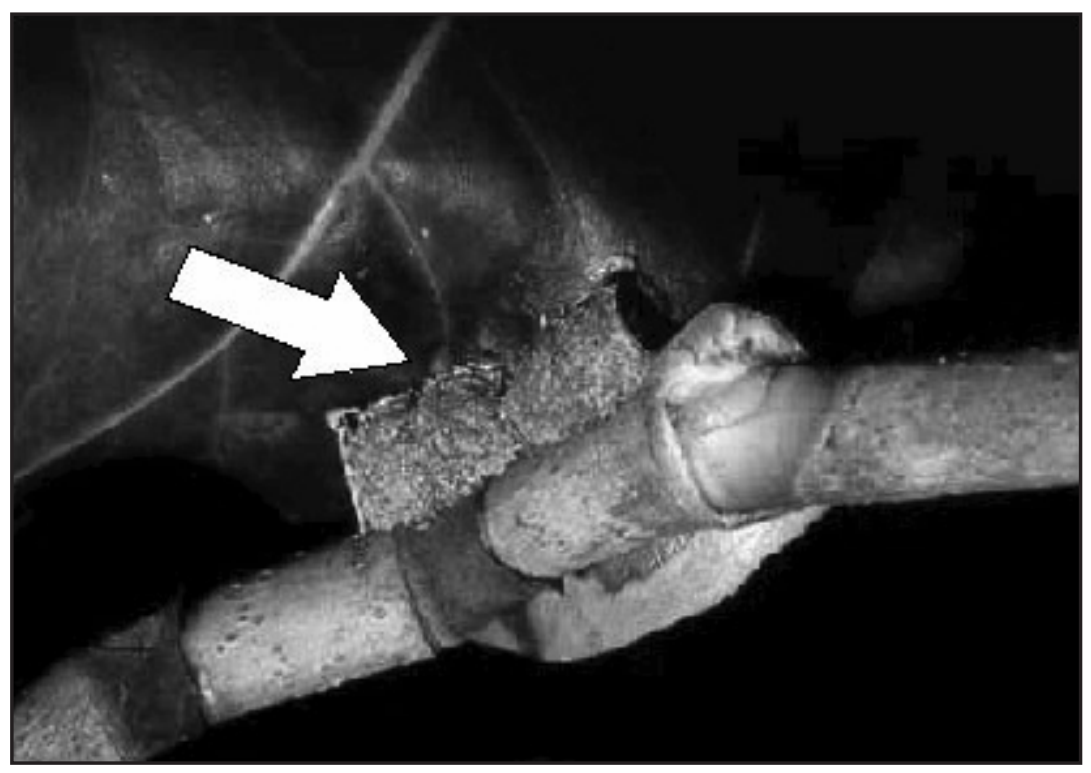

Fig. 6. Cocoons of Sericoceros mexicanus.

small clusters of two to 10 (Fig. 6). Occasionally clusters of cocoons were seen attached to wooden picnic tables underneath or in close proximity to seagrape trees.

Pupation by the generation of larvae observed occurred after January 26 was not observed. Martorell (1941) reports that the period of pupation for $S$. krugii is about 20 days.

\section{Natural Controls}

No occurrences of parasitism or predation were observed. During the final days of observation, two instar IV larvae were seen exhibiting classic symptoms of NPV infection: flaccid bodies hanging from leaves and attached to the leaf by the abdomen. Smith and Janzen (2002) report parasitism of $S$. mexicanus by a species of Vibrissina (Diptera: Tachinidae) in northwestern Costa Rica.

\section{Number of Generations}

The limited time during which observations were made precluded determination of the number of generations per year. Discussions with local residents indicate that at least two periods of defoliation occur per year occur, one in January and another in August. Whether this represents periods during which larvae have been noticeably abundant or two actual generations requires further study.

\section{Hosts and Relative Abundance}

Seagrape, Coccoloba uvifera, was the only host of Sericoceros mexicanus on Roatán Island. On Roatán, seagrape is found only on sandy beaches above the average high tide line. Consequently, infestations were restricted to these areas. Defoliation of other indigenous trees and shrubs was observed but was attributed to leaf-cutting ants.

During January 2002, heaviest populations of S. mexicanus were seen in the West Bay area of Roatán Island where on some trees, almost every leaf had a colony of larvae. Adults and larval colonies were also present on seagrape trees near the community of West End but in smaller numbers. Examination of seagrape trees at Palmetto Bay, on the northern shore of Roatán Island on January 21 resulted in the detection of only two larval colonies.

\section{Impacts}

Defoliation by Sericoceros mexicanus, at least on Roatán Island, appears to cause little or no permanent injury to seagrape. Trees refoliated at the time when defoliation of older foliage became conspicuous, thus masking the damage. A few larger, older seagrape trees were seen with branch dieback, a common phenomenon of repeated tree defoliation in temperate climates. However, it could not be determined if the dieback was the result of defoliation. The larvae or adults are not considered a nuisance because they spend all of their life cycle on or near seagrape trees. Local residents regard the insect as a curiosity rather than a pest.

\section{Acknowledgements}

I thank Jose Negron, USDA Forest Service, Rocky Mountain Research Station, Fort Collins, CO and Chester Moore, Centers for Communicable Diseases, Fort Collins, CO, for providing the initial clues to the identity of this insect. Formal identification of Sericoceros mexicanus was made by Nathan Schiff, USDA Forest Service, Southern Research Station, Stoneville, MS and David R. Smith, USDA Systematic Entomology Laboratory, National Museum of Natural History, Smithsonian Institution, Washington, D.C. Jose Negron provided laboratory space and equipment for larval head capsule measurements and David R. Smith provided the distributional records shown in Fig. 1. Review comments were provided by Nathan Schiff and David R. Smith.

\section{References}

Becker, G.C. and D.M. Benjamin. 1964. Biology of the Swaine jackpine sawfly in Wisconsin. Canadian Entomologist 96: 589-599.

Becker, G.C. and D.M. Benjamin. 1967. The biology of Neodiprion nigroscutum (Hymenoptera: Diprionidae) in Wisconsin. Canadian Entomologist 99: 146-159.

de Souza Dias, B.F. 1975. Comportamento pré-social de sinfitas do Brasil Central. 1 Themos olfersii (Klug) (Hymenoptera: Argidae). Studia Ent. 18 (1-4): 401-430.

Dyar, H.G. 1890. The number of molts of lepidopterous larvae. Psyche 5: 420-422.

Gilman, E.F. and D.G. Watson. 1993. Coccoloba uvifera, Seagrape. USDA Forest Service and Southern Group of State Foresters. Fact Sheet ST-175. 3 p. 
Hard, J.S., T.R. Torgersen and D.C. Schmiege. 1976. Hemlock sawfly. Forest Insect and Disease Leaflet 31. USDA Forest Service. $7 \mathrm{p}$.

Martorell, L.F. 1941. Biological notes on the sea-grape sawfly, Schizocera krugii Cresson, in Puerto Rico. Caribbean Forester 2(3): 141-143.

Smith, D.R. 1992. A synopsis of the sawflies (Hymenoptera: Symphyta) of America south of the United States: Argidae. Memoirs of the American Entomological Society. No 39. 201 p.

Smith, D.R. and E. A. Benitez Diaz. 2001. A new species of Sericoceros Konow (Hymenoptera: Argidae) damaging villetana trees, Triplaris caracasana Cham. (Polygonaceae) in Paraguay. Proc. Entomological Society of Washington 103(1): 217-221.
Smith, D.R. and D. Janzen. 2002. Food plants and life histories of sawflies of the family Argidae (Hymenoptera) in Costa Rica with descriptions of two new species. Journal of Hymenoptera Research (in press). VanDerwerker, G.K. and H.M. Kulman. 1974. Stadium and sex determination of yellowheaded spruce sawfly, Pikonema alaskensis. Annals of the Entomological Society of America. 71: 615-618. 